\title{
Dancing Life Stories: Embodied Auto-bio-narratives
}

\author{
Christina Thurner
}

\begin{abstract}
Dance narrates with and through the body. How, why and in what way it does this diverges depending on historical, cultural and aesthetic contexts. Contemporary dance of the late 20 th and early 21st century no longer tells stories in a continuous, holistic way. These stories do not pretend to summarise entire (life) histories in their entirety, says German dance scholar Gabriele Brandstetter (2005: 130). Rather, they appear fragmented, brittle or marginalised, thus corresponding to the postmodern condition according to which no one single (hi-)story exists, only countless smaller stories (cf. Lyotard 1979). Individual stories and life meanings are layered onto the dominant narrative.

To tell smaller stories of one's life can even be considered today's fashion: not only does the genre of autobiography currently enjoy an extraordinary status in the field of literature-it has also arrived in theatre dance, performance and choreography in the form of what might be called dancing 'Auto-Bio-Narrations'. These 'Auto-BioNarrations' - which include for example Simone Aughterlony's We need to talk (2011), Meg Stuart / Damaged Goods' Hunter (2014) or Wayne McGregor's Autobiography (2017) - simultaneously show and reflect on specific aspects of current dancing (life) stories. A central part or agent of our lives is our body. But how can a body narrate a life? And what can physically and scenically be told about telling the or $a$ (hi-)story? Analysing the aforementioned pieces by focusing on aspects of embodied (auto)biographical narration can help us gain a better general understanding of the methods, possibilities and potentials of embodied narration and of life stories in our time.
\end{abstract}

Dance tells a story with the body. How, why, and in what manner it does this, however, varies according to historical, cultural, and aesthetic contexts. Narratives are not fundamental for every form of dance - rather, one can observe a wave-like pattern of affirmation and repudiation of narrative throughout the history of dance. ${ }^{1}$ Thus the 18th-century reformers of ballet (from John

1 Of course, this is not evolutionary, i.e., this should not be understood as a linear sequence,

(C) CHRISTINA THURNER, 2021 | DOI:10.1163/9789004462632_010

This is an open access chapter distributed under the terms of the CC BY 4.0 license.

Christina Thurner - 9789004462632 
Weaver and Gasparo Angiolini to Jean Georges Noverre; see also the chapter by Fenböck in this volume) distanced themselves from the spatially structured baroque Ballet de Cour by promoting the return of the danced story, and at the same time invoking ancient pantomime and its gesture conventions. ${ }^{2}$ The narrative Ballet en Action thus made itself comprehensible through a canonisation of expressive movements and through recourse to familiar material, preferably from ancient Greek mythology.

Various trends in choreography, especially since the beginning of the 2oth century, have rejected such a non-verbal narration through movement on the ballet stage. Modern dancers like Loïe Fuller or Isadora Duncan, but also later, neoclassical choreographers like George Balanchine wanted to leave narrative (once again) to other art forms and chose rather to express moods in dance, or to get away from narrative dramaturgy entirely in favour of routines that focus on musical or spatial structures, or on emotional states. ${ }^{3}$ From the 197os, German Tanztheater fell back onto narrative content; however, choreographers like Pina Bausch, Johann Kresnik, or Reinhild Hoffmann no longer told selfcontained stories from beginning to end, but rather put unfinished, fragmentary tales into the spotlight. ${ }^{4}$ They were not interested in preserving narrative continuity; rather, the dance picked up narrative motifs, and showed fragments of stories, with breaks, but also with open spaces. Bausch's montage pieces, for example, drew on episodes recalled from childhood or from her experiences with gender relations. A particular focus of Tanztheater lay, and still lies today, in 'small stories, ${ }^{5}$ i.e. in supposedly marginal, individualised events. One could argue that these 'small stories' from earlier in life or lived gender relations are characterised by an emphasis on corporality, in the sense of (physical or somatic) sensitivities, which are then perceived as such by the dance's recipients, or rather, which trigger corresponding responses in them.

but rather as different concepts of dance that exist concurrently side by side, or that overlap in their chronologies.

2 See, for instance, Weaver 1985 [1717]: 739-740, who holds that ancient pantomime told stories through hands, fingers, legs, and feet, without making use of the tongue. Various dance scholars have done research on narration in dance from the 17th to the 2oth century and on the narratology of dance: see, among others, Foster 1996; Bernkopf 2005; Nye 2008.

3 Schmidt 2002: 56 says of Balanchine that narrating stories had never been his business. On the relationship of 'formalism vs. storytelling' in Balanchine, see also Taper 1963: 48, according to whom Balanchine is supposed to have said that he was "certainly not interested in using beautiful dance movement merely as a caption for some silly story."

4 See Schlicher 1987: 46 .

5 This idea corresponds to the postmodern notion that small stories take the place of the big story(-ies), on which see Lyotard 1979. 
Such forms of narration contradict the common argument that storytelling has disappeared from the (dance-)stage of our present day. ${ }^{6}$ On the contrary, storytelling absolutely continues, in new, (self-)reflexive forms-with a broader concept of narrative. ${ }^{7}$ These are emphatically fragile, deliberately contingent narrative acts, which, as the theatre scholar Doris Kolesch writes, seek to rupture and undermine the closed narrative of a totalising system of history. ${ }^{8}$ These histories present themselves, according to the dance scholar Gabriele Brandstetter, as a collage of coincidences, commonplaces, and derivatives and do not feign the overview of a (life) story. ${ }^{9}$ Of course, this is not to be viewed as an isolated (stage) phenomenon, but applies generally to an attitude prevailing since the 1970s, which Lyotard describes as the "postmodern condition", ${ }^{10}$ and which other arts have also negotiated. In dance, this negotiation is now firmly bound to the body and its actions or possible agencies, which should no longer be presented as steeped in totalising history, but should be made available to the recipient's experience in their physical plurality and discontinuity. ${ }^{11}$

The impossibility of an overview of an (entire) life has been increasingly addressed in the so-called contemporary dance of the late 2oth and, even more, of the beginning of the 21st century. For example, as Martina WagnerEgelhaaf writes concerning literary autobiography, the modern subject is, since the 2oth century, increasingly aware of her/his proneness to crisis, and puts this at the centre of the reflection. ${ }^{12}$ In recent years, narratives have also frequently appeared on the dance stage which recount in, or rather, through dance 'small stories' from one's own life. ${ }^{13}$

One vivid example of this is found in Simone Aughterlony's We Need to Talk, from 2011. The dancer, performer, and choreographer Aughterlony ${ }^{14}$ ironically pushes the multi-layered, playful intertwining of (a) large-scale general and small personal story (or stories) to the limits. Aughterlony's piece connects

$6 \quad$ See, among others, Le Moal 1999: 757 .

$7 \quad$ See Brandstetter 2005: 117; also Thurner 2007, 2011, 2017 a.

8 Kolesch 2005: 219-220; cf. ibid.: "Not facts of reality or of history are the objects of representation, but the narration and the act itself of narrating in its mediality". All non-English quotations have been translated.

9 Brandstetter 2005: 130-131.

$10 \quad$ Lyotard 1979. Cf. also Brandstetter 2005; Engelmann 2004.

11 Cf. Brandstetter 2005; additionally Thurner 2008, 2017b.

12 See Wagner-Egelhaaf 2005: 10-11.

13 On which see Brandstetter 2018.

14 Originally from New Zealand, Aughterlony has been active in Zurich and Berlin since the early 20oos, first as a dancer in Meg Stuart's Damaged Goods and then as an independent choreographer and performer. Cf. also https://www.aughterlony.com/cv/, 22.11.2018. 
her own story - the biography of an individual human, born in 1977-with so-called world history, which —also in 1977-was even narrated for extraterrerestrials, when NASA's reports of world history (such as, for example, a record of the sound of our earth) were sent into space. Both events, Aughterlony's life and the Voyager Mission, coincidentally found their start in the same year. The dance artist deliberately allows dimensions to collide in her choreographed narrative, in that she showcases, links, and makes various co-presences productive: the simultaneity of the event (world history and the personal), and the manner of her narration (verbal and physical), as well as the conditions of its reception (the co-presence of the performer and the audience). Aughterlony physically, scenically, and verbally narrates major, (depending on the perspective) world-moving stories, and in contrast, very small, personal ones. The latter, however, ultimately affect the audience more, because each viewer (somehow, in their own way) has experience with them. Moreover, merging these personal stories with episodes of world history renders the latters' absurdity all the more obvious. Thus, Aughterlony's piece becomes the reflected embodiment of a life story in the large-scale as well as the small.

The cultural theorist Norma Köhler also notes that biographical storytelling is increasing on the stage ${ }^{15}$ - in parallel to the rapid upswing of autobiography in the field of literature (and literary studies).${ }^{16}$ She speaks even of a biography 'boom' in the performing arts, and regarding its nature and methods she writes: "From the variety of biographically-oriented media, in addition to the manifold forms of representations and strategies of performance, the recipient expects not only to be able to experience authenticity, but also to observe, and be able to relate to, how a person handles the task of artistically depicting their life". ${ }^{17}$

In this article, I would now like to examine these biographical representations more closely - specifically, these artistic, that is, choreographed narratives in contemporary dance. I employ the term 'embodied auto-bio-narration' in order to more closely encapsulate these danced or even dancing biographies-in correlation to auto-bio-graphies, i.e. written accounts of lives. ${ }^{18}$

15 Köhler 20o9: 11; see also Carlson 1996.

16 See Holdenried 200o: 37; see also Wagner-Egelhaaf 2018; Marcus 2018.

17 Köhler 2009: 11. According to this description, Köhler would in fact have to speak of an 'Autobiography boom'; however, 'biography' (the description of $a$ life) and 'autobiography' (the description of one's own life) are not always precisely distinguished in scholarship. In this article, autobiography or auto-bio-narration, respectively, mean the specific form of biography or bio-narration. Cf. footnote 18.

18 Cf. Holdenried 2000: 21: autobiography "can scarcely be more closely defined than through the explanation of the term's components: the description (graphia) of an individual's life (bios) by the self (auto)". 
These embodied auto-bio-narrations reveal and simultaneously reflect a specific aspect of current danced (life) stories. A central component or player in our life is actually our body. But how can a body narrate a life, whether one's own or another's? And what can be physically or scenically revealed about how the (or a) life is recounted? ${ }^{19}$

Based on the analysis of two examples-Meg Stuart's piece Hunter from 2014, and Wayne McGregor's Autobiography from 2017-I will, in the following, focus on some significant peculiarities of embodied (auto-)biographical narration in dance, with the goal of producing a better general understanding of the methods, possibilities, and potentialities of embodied narratives and (life) stories in our time.

The Dancing Body Digests Life-Meg Stuart's Hunter $(2014)^{20}$

"How can I digest the many influences and traces that shaped me as a person and artist?" the choreographer and dancer Meg Stuart ${ }^{21}$ asks in the press kit for her piece Hunter, where she identifies it as autobiographical. ${ }^{22}$ And then: "How can my body unfold quantum genealogies and unrealized histories?"23 Already here, Stuart points to the coupling of story and history, which in itself already contains an unmanageable array of options in possible progressions and narrative styles. As Stuart explained in an interview, she went on a search, or even a hunt, for how she had shaped her life in her environment and with her body: "Back in time, you hunt for clues to who you are, for patterns in the choices you have made, for the things that got you where you are now."24 These statements reveal a reflection on how one's own life can be (physically) processed, narrated, and choreographically performed.

19 See the chapter by Crawley in this volume, who discusses similar questions.

20 I covered this piece in the Fall semester of 2017, in a seminar on Autobiography in Dance at the Institute of Theatre Studies at the University of Berne. I thank the students for their input and for the discussions, the results of which have been included in this essay.

21 The American Meg Stuart has been active in Europe since 1991 (largely in Belgium, Switzerland, and Germany); she founded her company Damaged Goods in 1994. Cf. http://www .damagedgoods.be (21.11.2018).

22 Stuart / Damaged Goods 2014b: 2.

23 Stuart / Damaged Goods 2014b: 2.

24 Cf. http://www.damagedgoods.be/en/hunter, 28.11.2018; also Stuart in Bellon 2014: 19. On the image of the hunt and the piece's title, cf. Luzina 2014: "she is not only a collector, but also a hunter. She picks up the things she finds and digs into the deepest layers of memory" (Stuart / Damaged Goods 2014b: 14). 
The piece premiered on 26 March 2014, in Berlin's Hebbel am Ufer Theatre (HAU). It then toured Germany, Belgium, Switzerland, Italy, France, the USA, and Canada, among other countries. ${ }^{25}$ This was Meg Stuart's first full-length solo, ${ }^{26}$ and she was, at the time of the premiere, 49 years old. ${ }^{27}$ Stuart herself spoke of this in an interview: "This time I really started choreographing on my own body again, making movement studies, curious of how my age [laughs], my experience, and all the work that I've been producing and the material that I've been exploring, have influenced me and my movements. So in the preparation I went through my personal archive: the work, but also the family history archive, Super 8 tapes, photos ...". ${ }^{28}$ Everything that she could find, both in the fund of her possessions (recollected material) and her body (learned movements, encoded postures, remembered choreographies, etc.), potentially becomes a testimony to her past, to her own (hi)story.

The piece begins with a kind of bricolage scene. Stuart, or rather, her persona on the stage is making a handicraft out of her life: she cuts, glues, paints, and overwrites photographs and other lost-and-found objects (most of them into an unrecognisable state). She sits all the while at a table. What she produces is also displayed for the viewers as a projection, since the actress' activity is filmed and projected onto the back wall of the stage. The projection repeatedly zooms in onto the craftwork.

This prologue, from its beginning, draws attention to the constructedness and processuality of what it shows. The public receives a moment in the life story of a figure, who retrospectively compiles, or rather, crafts herself. ${ }^{29}$ Stuart here reveals what the American theatre scholar Marvin Carlson already established in the 1990s regarding performance art: "[A]utobiographical performance has become much more self-reflexive, much more aware of its own

25 I saw the piece live on 28.06.2014 at the Venice Bienniale, and Stuart's company Damaged Goods kindly provided me with a filmed recording from a performance in Ghent on 19.2.2016, produced by Mountain View, https://vimeo.com/195619114 (password protected), 21.11.2018.

26 Stuart / Damaged Goods 2014b: 2. Cf. Stuart in Bellon 2014: 19: "The solos I did make since Disfigure Study [1991] were all kind of side projects between group pieces."

27 Cf. the statement of autobiography scholar Michaela Holdenried: the "classic works [of autobiography] are late works" (Holdenried 2000: 30). One could, however, debate what role age plays in dance (in contrast with other arts) as well as for Stuart's motivations in this piece.

28 Stuart in Bellon 2014: 19.

29 This scene is comparable to the prologues or forewords of written autobiographies, in which the author states something about how he/she has proceeded, how he/she approaches the genre of autobiography, etc. 
constructedness, and much more willing to make this awareness itself part of the presentation." 30

The 'reality' that manifests itself in the performer's physical presence and the accompanying memorabilia from her own life ${ }^{31}$ blends with the 'created' element of the show, as well as the projection (in a literal as well as in a metaphorical sense). Furthermore, the bricolage in Stuart's piece revolves on a turntable while it is worked. This associates it with a certain understanding of history and biography that is not based on linearity, but that depicts a circular structure and whose movement, that is, whose process remains revolving and revisable. From off-stage, we hear voices, fragments of conversations, and music, which likewise-so we sense-(should) enter the performed reconstruction of Stuart's life, and which round off the visual, kinesthetic, and haptic memories that are shown to us.

Throughout its $1 \frac{1}{2}$ hours, Meg Stuart's embodied auto-bio-narrative Hunter builds a choreographed life story from scenes featuring non-verbal movements, spoken language, acting, and objects. Anyone who has followed the (life) work of the choreographer over the last decades recognises many citations and references to earlier pieces. Or they identify, in the danced passages, Stuart's characteristic language of movement, which consistently explores physical boundaries and drives them to (seeming) physical destruction, where the dancer registers surprising and striking moments of vulnerability, melancholy, longing, lust for life, or even pleasure. For those familiar with Stuart, this reveals artistic auto-bio-narration as a kind of demonstration that retrospectively surveys her own work as a choreographer/dancer. Anyone without prior knowledge of Stuart's oeuvre, however, is nonetheless shown a wealth of fragmented stories and events, which are presented as a process of the digestion of separate 'small' stories. This variety of episodes and processes, of choreographically-staged and -performed creative effects, underlines what Stuart has spoken of as "the many influences and traces that shaped me as a person and artist". ${ }^{32}$ The combination of the private persona and the public artist, moreover, mirrors the constellation of a dance solo, in that the choreographer, as a dancer, performs his/her piece with his/her own body.

After about half an hour, Stuart also drags large projection screens, in the form of plexiglass plates, onto the stage. She appears on each of them differently_(i.e., each shows her body, her form, her shadows, etc., in another light,

30 Carlson 1996: 6o4.

31 On this, see Stuart / Damaged Goods 2014c: "All of it is real, I was told afterwards. The photos, the video footage, the voices (her brother): it all really is from her past."

32 Stuart/Damaged Goods 2014a: 2. 
or with a differently coloured background, diffuse or clear). ${ }^{33}$ Everything is thus blended together: the physical and concrete with the projected and figurative. Before witnesses, so to speak, the performer plays with opposites, which - I would argue — characterise the embodied auto-bio-narrative as well as many other stories of our present day: reality and appearance, fact and fiction, authenticity and virtuality. All of this crystallises in one performing person, who is simultaneously the (physically present) author and actor of her story and her life.

In the last third of the piece, the dancer Stuart begins an almost classic, because verbal, life narration, which, however, she introduces with the remark: "I certainly didn't trust words for a long time and there was a big part of my life where I didn't talk much at all." ${ }^{34}$ She further says that because of her childhood experiences (her father ran an amateur theatre), she had sworn that she herself would never speak on stage. This confession forms the ironic beginning of a monologue, the like of which had never before been seen or heard from Stuart. But why, of all things, does Stuart speak in a dance piece, and what's more, in a piece described as autobiographical? It seems almost as if she is exposing our expectations of a narrated life story: the viewers hear the described episodes from the biography, the characterisations and confessions, and involuntarily manufacture from them-despite the initially expressed mistrust towards speech-a direct connection between the speaker and the life of which she speaks. Verbal auto-bio-narratives are immediately recognised as narratives from an individual's life, while non-verbally portrayed narratives are much more difficult to grasp as such. So do we sooner believe words, when it comes to the narration of (one's) life? Do we more easily recognise in them-although conveyed through speech-a (seeming) (auto-)biographical authenticity? In this scene and with her piece, Stuart calls direct attention to this fact-i.e., to the hegemony of words, and the obvious logocentrism of the autobiographical genre-and simultaneously undermines it. She does this in the way that she, as a dancer and choreographer, expresses her scepticism. While she speaks, she is always physically present, i.e., her body accompanies or contrasts the seemingly unambiguous verbal and literal speech with the characteristically diverging gestures of her language of movement. Thus she contrasts the 'pure' verbal speech against the moved scenes, which, for their part, suggest something particular and personal, that is to say, an individual, ambiguous body. In her phys-

33 Cf. Stuart / Damaged Goods 2016, https://vimeo.com/195619114 (password protected), from oо:31:00.

34 Cf. Stuart / Damaged Goods 2016, https://vimeo.com/195619114 (password protected), from 1:04:45. 
ical presence as a moving person, she shows, when speaking, that she mistrusts speech, in order to reflect directly on what has been said (i.e., the contents and the performative production of the narrative).

According to research into literary autobiography, which draws on Philippe Lejeune, there is a pact in autobiography that the author gives his or her assurance, in an 'explanation', that the work is autobiographical, and the reader accepts this. ${ }^{35}$ Could such a pact also be understood in relation to the stage piece Hunter? A fitting explanation can be found on Meg Stuart's/Damaged Goods' home page: "In her evening-length solo Hunter, choreographer Meg Stuart explores her own body as an archive populated with personal and cultural memories, ancestors and artistic heroes, fantasies and invisible forces. Discovering traces in the land of small things that linger around her body, Stuart translates them into a series of self-portraits." ${ }^{36}$ Yet this explanation is (markedly) complex. On the one hand, the recipient of the piece is offered the same pact, namely in that they are ascertained that the piece is about personal memories, about Stuart's own body, with which she stands on the stage, and therefore, about Stuart herself. On the other hand, the quoted statement also suggests that the piece apparently undermines an overly seamless conflation of the autobiographical narrator and a coherent 'self'. Cultural memories emerge alongside the personal ones; the body is not the person, but is rather declared to contain an archive of episodes and energies, which in turn do not produce a 'self', but a number of self-portraits. On another occasion, Stuart says in an interview with Michael Bellon: "I also explore possible parallel lives and worlds ... [Interviewer:] So the piece is not a chronological personal diary or overview of your work. Stuart: And it isn't a direct translation either. It has the form of a collage ... I make all sorts of associations and juxtapositions; I also use fictional selves and bodies, so the material is all first-hand and has its own complexity." ${ }^{37}$

The embodied auto-bio-narrative is thus explicitly presented here as something open, multiple, and even free, which questions the logic of the identity of the author, narrator, and protagonist, ${ }^{38}$ long-established in (research into) literary autobiography, as well as the factuality of what is presented. As an artist, Stuart goes beyond her own 'self', or rather, beyond any one's own, and addresses in general the constitution of the self as a multi-faceted performat-

35 See Holdenried 2000: 27; Lejeune 1975.

36 Stuart / Damaged Goods. 2014a (http://www.damagedgoods.be/hunter, 29.11.2017).

37 Stuart in Bellon 2014: 19 (emphases of the original text).

38 See Wagner-Egelhaaf 2005: 10. She is clear that this identity is also questioned, and a degree of fiction readily accepted, even if not required, in newer literary autobiography (studies). 
ive (narrative) act. This goes for her art, one could argue, just as for other arts, which likewise reflect the constitution of the self as a performative narrative act. ${ }^{39}$ As a dance artist, though, Stuart plays with how the performative creation of a 'self' through a tangibly present body (still) contains (as she says) its own complexity, but also specific potential. The fictive and factual, imaginary and material/materialised, are shown, in the physical performative process, as reinforcing, interrelated variables. They disintegrate as opposites in and through the showcased body, as it performs a moving auto-bio-narrative reflection, and so, at the same time, performs and creates.

Additionally, the audience to whom this auto-bio-narrative is offered also contributes to the performance. They choose, through their respective receptive attitudes, whether the pact is successful, i.e. whether to accept and reflect on Stuart's performance as autobiographical. Gabriele Brandstetter points to this broadly in her essay Autobiography in/as Dance, when she writes: "The viewer (like the reader) has a crucial constitutive function for bringing about the 'performative contract'". ${ }^{40}$ The homepage of Damaged Goods further states that in Hunter, "interior stages refract and resonate in a shared world", ${ }^{41}$ thus referring to both the resonances between different stages and states in the actor's life, and the resonances between Stuart and the audience with whom she shares her world (and vice versa). For each person, as a review of the piece in Utopia Parkway says, "[has] lived a life, ... collected thoughts, sounds and images along the way. Hunter is the Meg Stuart way of dealing with that, and she does so, not only in a strangely beautiful, but also in a very contemporary way, in this world in which everybody is coping with an information overload." 42

The piece Hunter-to sum up-is therefore an embodied auto-bionarrative, which also simultaneously brings all the components of this term back into question: it addresses the im-/possibility of narrating a life in its entire multiplicity, as well as the question of how to access the 'individual', which is also always a 'universal', or at least something shared. And finally, the embodiment is set beside the spoken narration, and both types of expression, or rather, communication, are confronted with each other, opposed to one another, and, quite intriguingly, linked to one another. A story is told with and

39 See the literary constitution of the self as a performative narrative act in Max Frisch's Mein Name sei Gantenbein-I owe this reference to Karin Schlapbach.

40 Brandstetter 2018: 542.

41 Stuart / Damaged Goods. 2014a (http://www.damagedgoods.be/hunter, 29.11.2017).

42 Stuart / Damaged Goods 2014c: 17-18; cf. the response of the unnamed critic, ibid. 17: "There is no way you can capture everything, and remember everything. Hunter reminded me of that feeling. It presents someone trying to tell you about everything." 
through the body, which itself as much ventures to tell the story as it fundamentally mistrusts narrative. In the end, regarding the status of its narration, Hunter exemplifies what Carlson has broadly framed with respect to autobiographical performance: "Both narrative and narrator are constructions." ${ }^{33}$ Thus the danced auto-bio-narrative becomes a physically present, performed, or rather, created, dynamic, danced life project before an audience.

\section{DNA-Episodes in Random Mode-Wayne McGregor's Autobiography (2017)}

The British choreographer Wayne McGregor takes an entirely different approach to the danced narration of life stories. ${ }^{44}$ If Autobiography were not the title of the piece, the fact that the piece is the narrative of a (personal) biography might perhaps not emerge solely through seeing the piece. But this theme, or rather, embodied narration, is not a simple issue in this choreographic example either. The audience observes 80 minutes of highly aestheticised, danced episodes, for each of which a numbered title is projected. ${ }^{45}$ The piece begins with ' 1 avatar'; 46 it does not proceed in numerical order, and so the next titles might be, for example, ' 16 world' 47 or ' 7 traces' 48 or '19 ageing'; 49 it finally ends with ' 23 choosing.. ${ }^{50}$ The ten virtuoso, ballet- and contemporarytrained dancers respond with solos, duets, and group formations, in varying qualities of motion, to the compositions of the electronic musician Jlin, which range from gentle clangings over melodic allusions to baroque and pop

\footnotetext{
43 Carlson 1996: 604.

44 McGregor $\left({ }^{*} 1970\right)$ is the artist in residence at Sadler's Wells in London, together with his Company Wayne McGregor, founded in 1993. Cf. McGregor 2017, https://waynemcgregor .com/about/wayne-mcgregor/, 28.11.2018.

45 For my analysis, I rely on a recording from $7 / 10 / 2017$ in Sadler's Wells, which the Company kindly provided for me: McGregor 2017, https://vimeo.com/277430565 (password protected), 28.11.2018.

46 McGregor 2017, https://vimeo.com/277430565 (password protected), 28.11.2018, from o०:००:24.

47 McGregor 2017, https://vimeo.com/277430565 (password protected), 28.11.2018, from oo:10:36.

48 McGregor 2017, https://vimeo.com/277430565 (password protected), 28.11.2018, from oo:33:13.

49 McGregor 2017, https://vimeo.com/277430565 (password protected), 28.11.2018, from o०:45:20.

50 McGregor 2017, https://vimeo.com/277430565 (password protected), 28.11.2018, from 01:13:12.
} 
music, to rhythmic electrobeat and futuristic-atmospheric songs. In the interplay between choreography, music, ambitious light design, ${ }^{51}$ projections, and stage elements ${ }^{52}$ (like the raising and lowering of metal frames), widely varying moods are created. The viewers are catapulted from a heartfelt, gentle duet between two men into artificial-seeming worlds with scattered, strange-acting beings; from a woman's somnambulously serene, expansive solo, the viewer falls into the middle of a-spatially oppressive-nightmare. Or: in the seeming harmony of various duets, other scenes sneak in, disruptions of physical coordination, which then again contrast the exuberantly life-lusting, rhythmically and technically thrilling group formations.

Autobiography could be received as a choreographically challenging, purely formal-aesthetic piece, if, as mentioned, it did not bear this title, which explicitly underlines further levels of meaning. What, however, one inevitably asks oneself, is autobiographical about this work? The title can also be understood as a suggestion of an autobiographical pact, which—as was already explained above-is first given simply through the idea that the author gives his or her assurance, in an explanation, ${ }^{53}$ that the work is autobiographical, which the viewer would then have to accept so that the pact may work. In McGregor's piece, the narrative is present through the title and, additionally, through the dramatic texts that accompany the piece (which I shall momentarily discuss). The question is now whether the piece is also accepted by the viewers as autobiographical, i.e., whether and how the danced, or rather, embodied narrative can be experienced as autobiographical.

It is certainly unlike other autobiographical pieces. For example, I showed that although Meg Stuart's Hunter also playfully questions and reflects on the autobiographical pact, it nonetheless renders it plausible and graspable in her embodied narrative. In contrast, Autobiography, as a group piece, seems even further removed from the simple implementation of a receptive agreement on this matter. For why is an autobiographical pact offered to the viewers, anyway? And who does the term 'auto' stand for here? The choreographer, or the individual dancers? Whose life is being written or narrated here? By whom exactly, and how? Anyone who engages with these questions, and thereby enters into McGregor's game of meanings, finds answers first of all in the piece's texts. These frame the choreographical presentation discursively, which in turn produces a suspenseful relationship of its own between (explanatory) narra-

$51 \quad$ Responsible for light design: Lucy Carter.

$5^{2}$ Stage and projection: Ben Cullen Williams.

53 Holdenried 2000: 27. 
tion and choreographical creation, to be discussed below. As the dramaturge Uzma Hameed writes on the relevance and understanding of autobiography as a genre: 'In this age of virtual reality and social media, autobiography is alive and well, perhaps not as a book of boring details.' ${ }^{54}$ Autobiography —as the quotation suggests - seems to function differently than a printed, verbal autobiography. Readers of the dramaturgical text discover that while McGregor distances himself from the classic concept of autobiography (even quite judgementally), he nevertheless takes it literally as 'Auto/bio/graphy', by declaring, on the one hand, that he investigates its "semantic constituents ... = self, life and writing." ${ }^{\prime 5}$ On the other hand, he calls into question "this layered, luminous and evanescent notion of lifestory":56 "At the opposite end of the spectrum is the life that intrigues choreographer Wayne McGregor: life as mutable present playing out unrepeatably moment to moment, into an array of possible futures. 'Autobiography doesn't have to be nostalgic or commemorative,' he comments. '(...) Your life, at any given moment is fractured, multiplicitous, felt. It's the sum of your impressions and experience, what you're reading or thinking about, who you're with. It exists across time and yet, in the telling, you're supposed to order it conveniently in time-and into something that makes narrative sense." 57 With Autobiography, McGregor sets a classic narrative meaning against an embodied one, where embodiment is not to be understood as a boundary to verbal narration, but rather as an experiment, a test site, in order to place embodiment and narration in a particular relation to each other, which will be explained more precisely below.

The (chronological) concept of time is significant in the above quotation, especially in McGregor's passages. He addresses it and refers through it to a classic understanding of autobiography, only in order to question it, first of all in reflecting on the piece's genesis. However, literary scholar Michaela Holdenried also points out that the genre of autobiography no longer (only) emanates from chronological life history; into its place have stepped dissociated chronologies and lived organisations of time. ${ }^{58} \mathrm{My}$ own dance studies argument also focuses on lived organisations of time.

In the art form of dance, choreographic-narrative arrangements of time are rarely chronological; dance operates in three-dimensional space, with not only successive, but also adjacent, or rather, interconnected activities and overlap-

\footnotetext{
54 Hameed 2018: 5 .

55 Hameed 2018: 5 .

56 Hameed 2018: 5 .

57 Hameed 2018: 5 .

$5^{8}$ Holdenried 200o: 46.
} 
ping temporalities. ${ }^{59}$ We see this in McGregor's piece: the autobiography is told - especially as it is a group piece-in a way that is not comprehensible in a linear fashion. It is, rather, split up into a number of storylines, which are intentionally divergent but always tangentially connected. The dramaturge writes on this concept: 'Under the heading of 'Self', McGregor has worked with his ten dancers to create choreography from old writings, personal memories, pieces of art and music that have been important in his life-a school photo, a poem ... From these elements a library of movement material has been generated: twenty three 'volumes' of a life". ${ }^{60}$ We come to see this as the explanation of how different autobiographical investigations were included in this piece. On the one hand, the individual dancers thus recount, through dance, something from McGregor's (own) life, which then is presented in the ensemble as the choreographer's embodied auto-bio-narrative. The fact that Autobiography is not one person standing on a stage, but a number of people, marks a striking difference from Stuart's Hunter. Whereas in McGregor, the author and the 'vehicle' of the tale - that is, the dancers - are at first two entities, these come together in Stuart's danced passages, where she acts as choreographer and dancer. However, the auto-bio-narrative works similarly in both pieces, if one understands that the author's life is embodied in the dance that he/she designed. The body of the performer becomes the carrier or - as the journalist Angela Heide writes in her review of the piece - the archive, from which a remembered life story is created, although actually "nothing is tellable in its infinite multidimensionality, let alone one's own life, what is experienced, observed, overlooked, unnoticed on account of inattentiveness or sheer overload". ${ }^{61}$ Hence McGregor's work is clearly in line with Stuart's reflection on the im-/possibilities of embodied autobio-narration.

On the other hand, there is nevertheless a further semantic dimension to Autobiography, in addition to the arrangement of a number of participants. It is not by chance that the choreographer refers to the number 23 , having created 23 autobiographical sequences with his dancers as 'volumes' of the respective 'life library'.62 The number 23 also refers to "the number chosen to reflect the 23 pairs of chromosomes which contain the human genome", which

59 Non-linear dance narrativity is also discussed in the chapter by Gianvittorio-Ungar in this volume.

6o Hameed 2018: 5 .

61 Heide 2018.

62 Their sequence and selection in each performance are determined by an algorithm (for the software: Nick Rothwell), so that—apart from the beginning and end—no performance is identical. See Hameed 2018: 2-3. 
McGregor himself had had sequenced "as part of The Genetics Clinic of the Future research study", in order to choreographically process it again in the piece Autobiography, "refracted and abstracted" as a "genetic story" with its "genomic principles of replication, variation and mutation".63 The scientistic experiment becomes a choreographical process and thus an ordering principle of the danced story, even though the movements, thus generated and arranged, do not make this correlation evident for the viewer. ${ }^{64}$ The self- (auto) story, which is here based on memories, is understood in the piece as a genetic life story (bio), as it rests on a scientifically-focused, biological structure, whichas is, at any rate, declared - ${ }^{65}$ apparently corresponds to the genome of the choreographer. This structure, in turn, is then translated into a choreographed principle of randomisation by selecting prefabricated danced scenes, which are newly arranged for each performance. This means that, each time, there results a contingent, embodied auto-bio-narrative. Therefore an (individual) life is also danced in this piece, even if it is decidedly unlike what is customary in the autobiographical genre and, furthermore, unlike what is found in Stuart.

The British dance journalist Judith Mackrell, a connoisseur of McGregor's work, also writes on his unconventional approach in her review of the piece for the Guardian: "It is however entirely typical of him that the piece owes very little to the conventions of personal memoir and that its starting point is

63 See Hameed 2018: 5-6: "the number chosen to reflect the 23 pairs of chromosomes which contain the human genome-refracted and abstracted through McGregor's choreographic processing, which is itself driven by genomic principles of replication, variation and mutation. 'Bio' or 'Life' therefore relates to the genetic story ... In the summer of 2017, McGregor's entire genome was sequenced as part of The Genetics Clinic of the Future research study ... In this piece, book-ended by a fixed beginning and end, a number of choreographic events from the 23 volumes in the 'life library' are selected and sequenced afresh for every performance by an algorithm based on McGregor's genetic code, in collaboration with software architect Nick Rothwell." As we additionally learn, ibid. 5: "AUTOBIOGRAPHY marks the beginning of a new direction, in collaboration with scientists at the Wellcome Trust Sanger Institute-as the first in a series of projects exploring dance and genetics."

64 Other contemporary choreographers, e.g. Merce Cunningham, also explicitly draw on scientific experimental methods.

65 See Hameed 2018: 6: "For each iteration of the piece, the computer randomly selects a different section of code from the choreographer's genome to determine which material the audience will see, performed by which dancers and in what order. The system dictates that no individual sequence of code can be used more than once, so that no two performances can ever be alike. Like DNA which is encoded through the four protein bases A-T-C-G in ever varying combination, and achieves mindboggling complexity from almost laughable simplicity, AUTOBIOGRAPHY reinvents itself endlessly." 
the science of genetics." ${ }^{\prime 6}$ This means that McGregor expands the performance of a danced life story by presenting his very own, deliberately divergent interpretation of a possible narrative. Meg Stuart-in comparison-takes autobiographical conventions as a starting point for her embodied auto-bio-narrative, but she reflects on these through her unique choreographic-performative approach. Both-Stuart and McGregor, together with his dancers-tell life stories in their pieces, which in turn cast doubt on the very possibility of narrating them in a consistent way.

\section{3}

\section{Conclusion}

Thus we arrive once more at the questions presented at the beginning of this essay: how, why, and in what way dance narrates—or rather, what is specific to its narration. Since at least the 18th century, when dance narrates, it does not just narrate, but also always reflects on the conditions under which this has to occur (in comparison to other arts), and what has been gained by it. Ballet reformers like John Weaver, Jean Georges Noverre, and Gasparo Angiolini extensively discussed these questions in their writings, and finally agreed on specific narratives on the stage, which to them seemed gesturally narratable, and indeed, whose gestural narrative should have an impact surpassing that of other modes of expression, and thus should establish dance as a respected art form. ${ }^{67}$ Others-each with their own interests and means—-have followed them in this approach.

If, therefore, a correlation is assumed here between narrative themes, danced modes of expression, and narrative strategies, one could say-in an admittedly rather abridged and schematic way, historically speaking-that each era and every form of dance tells that which moves them. It never, however, does this for itself, but rather always in a context and as a reflection of thematic discourses and choreographic approaches. Three central hypotheses thus underpin this article, with its focus on embodied auto-bio-narration in dance in the 21st century: (1) auto-bio-narration is a generally relevant theme in the 21st century, which (2) evidently currently also challenges the creators of dance to confront it in unique ways and (3) to find and test their own narrative techniques for it. It has been assumed that present-day choreographers are, on the one hand, searching for a way that their own life story can be told on

66 Mackrell 2017.

67 Cf. Thurner 20o9. 
the stage, and on the other hand, conversely, for what an embodied, danced, or better, dancing narrative can in turn mean for reflection on auto-bio-narration. While Meg Stuart targets physical processing and thus the question of who can 'digest' the influences that have shaped them - "that shaped me as a person and artist" ${ }^{\prime \prime}$ - McGregor draws on biological principles of organisation in order to negotiate the telling of a / his life.

In both, it is noticeable that the danced narrative does not speak for itself alone, but rather occurs consistently in confrontation with verbalised, or rather, written questions and reflections. It must be emphasised, however, that the embodiment of this reflection, which occurs finally in the co-presence of the audience, showcases the dance-specific potential of such an auto-bio-narrative, or rather, performatively puts it to a test. In the process, this embodiment creates other dynamic, moving possibilities of narration and particularly its reception, which are different from those characteristic of other (artistic) forms of expression.

Finally, it is clear that in both Stuart and McGregor, the embodied auto-bionarrative is, to begin with, a contention. The autobiographical pact is initially offered to the viewers in a verbal-discursive form, i.e., it appears in the title and/or in statements about the piece, which are communicated in texts (of the dramaturge, on the homepage, or in reviews or interviews with the artists). However, each negotiation of the autobiographical pact, its scrutiny and performative reflection, is nonetheless firmly choreographic, i.e., an embodied narrative presence. Thus these pieces look beyond the usual, mainly literarytextual, autobiographical genres, and test out new possibilities for how life can be narrated and viewed. The bodies on the stage tell decidedly danced life stories. At the same time, the pieces use the power of the word inventively and sophisticatedly for their purposes, but then they differentiate themselves from it and finally reflect this narrative power in dance, in a visually powerful kinesthetic performance, with and through the body, which is the embodiment of life. For without a body, neither dance exists nor a life that could be told.

\section{Translated from German by Caroline Bélanger}




\section{Bibliography}

Aughterlony, S. 2011. We need to talk (premiered 2011). https://www.aughterlony.com, 27.11.2018.

Bellon, M. 2014. 'Hunter: Meg Stuart's quantum shamanism.' In Agenda, 10.10.2014. Reprinted in M. Stuart / Damaged Goods: Presskit Hunter. 2014. Translated by Helen Simpson. p. 19 .

Bernkopf, A. 2005. Narrative Variants and Theatrical Constants. Towards a Dramaturgy of the Ballet Fantastique (1830-1860). University of Surrey: ProQuest Dissertations Publishing.

Brandstetter, G. 2018. 'Autobiography in/as Dance.' In Handbook of Autobiography/ Autofiction. Vol. 1: Theory and Concepts, edited by M. Wagner-Egelhaaf. Berlin / Boston: De Gruyter, pp. 542-546.

Brandstetter, G. 2005. 'Geschichte(n)-Erzählen in Performances und im Theater der Neunzigerjahre.' In Bild-Sprung. TanzTheaterBewegung im Wechsel der Medien. Berlin: Theater der Zeit, pp. 116-133.

Carlson, M. 1996. 'Performing the Self.' Modern Drama vol. 39, pp. 599-6o8.

Engelmann, P. 2004. Postmoderne und Dekonstruktion. Texte französischer Philosophen der Gegenwart. Stuttgart: Reclams Universal-Bibliothek.

Foster, S.L. 1996. Choreography and Narrative. Ballet's Staging of Story and Desire. Bloomington: Indiana University Press.

Hameed, U. 2018. 'Life (Re-)Writing.' In Company Wayne McGregor: Autobiography. Abendzettel. http://www.kampnagel.de/media/file/Sommerfestival_2018/Abendze ttel_Wayne_McGregor, 14.9.2018.

Heide, A. 2018. 'Company Wayne McGregor: “Autobiography”.' Tanzschrift, 14.4.2018. https://www.tanzschrift.at/buehne/nah-besehen/728-company-wayne-mcgregor-a utobiography. (Accessed: 29 November 2018.)

Holdenried, M. 200o. Autobiographie. Stuttgart: Reclam.

Köhler, N. 2009. Biografische Theaterarbeit zwischen kollektiver und individueller Darstellung. Ein theaterpädagogisches Modell. München: Kopaed.

Kolesch, D. 2005. 'Narration.' In Metzler Lexikon Theatertheorie, edited by E. FischerLichte / D. Kolesch / M. Warstat. Stuttgart: Weimar, pp. 217-220.

Lejeune, P. 1975. Le pacte autobiographique. Paris: Editions du Seuil.

Le Moal, P. (ed.). 1999. Dictionnaire de la Danse. Paris: Larousse.

Luzina, S. 2014. 'Der Riss in meinem Körper. Hebbel am Ufer. Die Tänzerin und Choreografin Meg Stuart zeigt ihr erstes abendfüllendes Solo "Hunter". In Tagesspiegel 28.3.2014, https://www.tagesspiegel.de/kultur/tanz-der-riss-in-meinem-koerper/96 79118.html. (Accessed: 22 November 2018.) English translation by Helen Simpson, 'The crack in my body.' In M. Stuart / Damaged Goods. 2014. Presskit Hunter, pp. 1314. 
Lyotard, J.-F. 1979. La condition postmoderne. Paris: Les éditions de minuit.

Mackrell, J. 2017. 'Wayne McGregor: Autobiography review-a mind-boggling mix of science and sorcery.' In The Guardian, 5.10.2017, https://www.theguardian.com/stage /2017/oct/o5/wayne-mcgregor-autobiography-review-sadlers-wells. (Accessed: 29 November 2018.)

Marcus, L. 2018. Autobiography. A Very Short Introduction. Oxford: Oxford University Press.

McGregor, W. 2017. Autobiography (premiered 2017). https://waynemcgregor.com/prod uctions/autobiography/, 28.11.2018; https://vimeo.com/277430565 (password protected). (Accessed: 28 November 2018.)

Nye, E. 2008. ' "Choreography” Is Narrative: The Programmes of the Eighteenth-Century Ballet d'Action'. In Dance Research 26.1, pp. 42-59.

Schlicher, S. 1987. TanzTheater. Traditionen und Freiheiten. Pina Bausch, Gerhard Bohner, Reinhild Hoffmann, Hans Kresnik, Susanne Linke. Reinbek b. Hamburg: Rowohlt.

Schmidt, J. 2002. Tanzgeschichte des 20. Jahrhunderts in einem Band. Mit 101 Choreographenporträts. Berlin: Henschel.

Stuart, M. / Damaged Goods. 2014a. Hunter (premiered 2014). http://www.damagedgoo ds.be/hunter, 13.6.2018.

Stuart, M. / Damaged Goods. 2014b. Presskit Hunter.

Stuart, M. / Damaged Goods. 2014c. Utopia Parkway: Beautiful cutting up and reassembling the past: 'Hunter'. 13.10.2014, https://utopiaparkway.wordpress.com/2014/ 10/13/beautifully-cutting-up-and-reassembling-the-past-hunter-by-meg-stuartdam aged-goods/. (Accessed: 22 November 2018.)

Stuart, M. / Damaged Goods. 2016. Hunter. https://vimeo.com/195619114 (password protected). (Accessed: 21 November 2018.)

Taper, B. 1963. 'Balanchine's Return to Russia.' In Bernard Harper's Magazine, November 1963, p. 47.

Thurner, C. 2007. 'Es war einmal-eine Erzählung. Narrative Spielarten.' In Zeitgenössischer Tanz. Körper-Konzepte -Kulturen. Eine Bestandsaufnahme, edited by R. Clavadetscher / C. Rosiny. Bielefeld: transcript, pp. 32-42.

Thurner, C. 2008. 'Zeitschichten, -sprünge und -klüfte. Methodologisches zur TanzGeschichts-Schreibung.' Forum Modernes Theater, vol. 23, no. 1, pp. 13-18.

Thurner, C. 2009. Beredte Körper-bewegte Seelen. Zum Diskurs der doppelten Bewegung in Tanztexten. Bielefeld: transcript.

Thurner, C. 2011. 'Erzählen mit dem Körper.' In Handbuch Erzählliteratur. Theorie, Analyse, Geschichte, edited by M. Martínez. Stuttgart: J.B. Metzler, pp. 56-58.

Thurner, C. 2017a. 'Tanz/Pantomime/Performance.' In Erzählen. Ein interdisziplinäres Handbuch, edited by M. Martínez. Stuttgart: J.B. Metzler, pp. 99-102.

Thurner, C. 2017b. 'Time Layers, Time Leaps, Time Lost: Methodologies of Dance Historiography.' In The Oxford Handbook of Dance and Reenactment, edited by M. Franko. New York: Oxford University Press, pp. 525-532. 
Wagner-Egelhaaf, M. 2005. Autobiographie. 2nd updated and expanded edition. Stuttgart: J.B. Metzler.

Wagner-Egelhaaf, M. (ed.). 2018. Handbook of Autobiography/Autofiction. 3 Vols. Berlin / Boston: De Gruyter.

Weaver, J. 1717. The Loves of Mars and Venus: A Dramatick Entertainment of Dancing, Attempted in Imitations of the Pantomimes of the Ancient Greeks and Romans. London. Reprint in Richard Ralph: The Life and Works of John Weaver. An Account of his Life, Writings and Theatrical Productions, with an Annotated Reprint of his Complete Publications. New York: Dance Horizons, pp. 737-764. 